\begin{tabular}{c|c|c}
\hline $\begin{array}{c}\text { JURNALPENELITIAN KEPERAWATAN } \\
\text { MEDIK }\end{array}$ & VOL. 1 NO. 2 & $\begin{array}{c}\text { EDITION: NOVEMBER 2018 - } \\
\text { APRIL 2019 }\end{array}$ \\
\hline & http://ejournal.delihusada.ac.id/index.php/JPKM & \\
\cline { 2 - 2 } RECEIVED: 20 JANUARI 2019 & ACCEPTED: 28 APRIL 2019 \\
\hline
\end{tabular}

\title{
HUBUNGAN FUNGSI AFEKTIF KELUARGA DENGAN KECERDASAN EMOSIONAL REMAJA DI SMA NEGERI 1 KECAMATAN PANAI HULU KABUPATEN LABUHAN BATU TAHUN 2019
}

\author{
Rentawati Purba, kurnia Novita Putri Harahap \\ Institut Kesehatan Deli Husadadelitua, Jl. Besar No.77 Deli Tua Kab. Deli Serdang \\ E-mail : rentawatipurba2@gmail.com
}

\begin{abstract}
One of the family vital function is affective function. Fulfilling the affective function of the family is defined as the ability of the family to meet the need for comfort and happiness. Adolescents are now very worried because they experience difficulties in emotional intelligence due to the lack of family support they receive and is at risk of the teenager doing negative things or deviating. This type of research is descriptive with an approach Cross Sectional to know relationship between family affective and adolescent emotional intelligence. Location of this research was conducted at SMA Negeri 1 Sub District Panai Hulu District Labuhan Batu and this research was conducted in November 2018. The sample of this study was students on SMA Negeri 1 Sub District Panai Hulu District Labuhan Batu which numbered 86 people whose sampling uses techniques Starified Random Sampling. Data analysis using test Chi-Square. Result of statistical test say, there is a relationship between family affective and adolescent emotional intelligence in SMA Negeri 1 Sub District Panai Hulu Dixtrict Labuhan Batu. The results of the study show the importance of good family affectuive functions so that adolescent emotional intelligence can be applied in a positive form.
\end{abstract}

Key Word : Between Family Affective, Adolescent Emotional Intelligence.

\section{PENDAHULUAN}

Pada awalnya, masa peralihan dalam fase perkembangan berada pada masa awal remaja. Masa peralihan yang dialami remaja merupakan masa yang paling di antisipasi oleh remaja tersebut dan terkhusus bagi orangtua. Apabila remaja mengalami masa peralihannya, orangtua tidak harus mengatur segala kegiatan yang akan dijalani dalam kehidupan nya melainkan orangtua harus membiarkan keputusan anak remaja nya tetapi orangtua tetap mengawasinya. Karena pada masa peralihan pada remaja, mendukung adalah tanggapan yang paling bijaksana yang dilakukan orangtua pada masa peralihan tersebut" (Sobur, 2016, hlm 121).

Edward Thorndike adalah sebagai tokoh psikologi koneksionisme, ia mengemukakan bahwa: Intelligence is demonstrable in ability of the individual to make good responses from the stand point of truth pr fact, artinya Intelegensi adalah kemampuan seseorang dalam memberikan suatu respon yang sangat tepat dan baik terhadap stimulus yang diterimanya" (Sobur, 2016, hlm 138).

Dalam buku Danniel Goleman, telah dilakukan survey besar-besaran di seluruh dunia yang mendapatkan hasil sangat mengkhawatirkan, yaitu generasi remaja sekarang lebih banyak mengalami kesulitan emosional daripada remaja generasi sebelum-sebelumnya, walaupun dalam keadaan ramai remaja malah merasakan kesepian dan lebih sering menjauhkan diri dengan orang - orang sekitarnya sampai menjadikan remaja itu pemurung, lebih 


\begin{tabular}{|c|c|c|}
\hline $\begin{array}{l}\text { JURNALPENELITIAN KEPERAWATAN } \\
\text { MEDIK }\end{array}$ & VOL. 1 NO. 2 & $\begin{array}{l}\text { EDITION: NOVEMBER } 2018- \\
\text { APRIL } 2019\end{array}$ \\
\hline & http://ejournal.delihusada.ac.id/index.php/JPKM & \\
\hline RECEIVED: 20 JANUARI 2019 & REVISED: 24 MARET 2019 & ACCEPTED: 28 APRIL 2019 \\
\hline
\end{tabular}

agresif dan sensitif jika terjadi masalah, lebih gugup dan mudah cemas serta tidak menghargai sopan santun (Goleman, 2018, hIm xvi).

Dukungan keluarga seperti adanya kasih sayang didalam keluarga, erat nya hubungan antar keluarga, adanya sikap saling mengerti, adanya suasana aman dan nyaman serta kepercayaan, saling menghargai dan saling harmonis dalam keluarga juga dapat mempengaruhi kecerdasan emosional yang dimiliki oleh remaja. Apabila remaja kurang mendapatkan dukungan dari keluarga tersebut atau bahkan dukungan keluarga tersebut tidak terpenuhi maka kecerdasan emosional yang dimiliki remaja tersebut akan menurun. Begitu juga sebaliknya, apabila remaja mendapatkan dukungan baik dari keluarga maka remaja tersebut akan memiliki kecerdasan emosional yang baik (Yuniar, 2016). Menurut penelitian Yusuf (2015) berpendapat bahwa Kurangnya dukungan keluarga yang diperoleh remaja akan mengakibatkan kestabilan emosi remaja menjadi menurun (Yusuf, 2015).

Berdasarkan wawancara pemula ataupun wawancara dasar yang peneliti lakukan di SMA Negeri 1 Panai Hulu Kecamatan Panai Hulu Kabupaten Labuhan Batu kepada beberapa guru yang mengajar di sekolah tersebut dan orangtua dari remaja, banyak orangtua dan guru mengeluh akan tingkah laku remaja tersebut yang tidak pernah mendengarkan nasehat yang diberikan oleh guru maupun orangtua. Dan remaja juga sering melanggar aturan yang ada di sekolah. Walaupun remaja sudah di hukum atas kesalahan yang sudah dia perbuat, namun semua itu tidak membuat remaja tersebut menyesali atas kesalahan yang sudah ia perbuat melainkan tidak memperdulikan hukuman-hukuman yang telah diberikan kepadanya.

Remaja saat sedang berada dirumah sangat jarang mau mendengarkan nasehat yang diberikan oleh orangtuanya. Ketika mendapat masalah, remaja cenderung untuk bercerita kepada teman yang sebaya dengan dirinya dan lebih percaya kepada temannya dibandingkan orangtua nya. Dari latar belakang tersebut peneliti tertaruk untuk melakukan penelitian mengenai Hubungan Fungsi Afektif Keluarga Dengan Kecerdasan Emosional Remaja di SMA Negeri 1 Kecamatan Panai Hulu Kabupaten Labuhan Batu.

\section{METODE}

Penelitian yang dipilih peneliti dengan cara kuantitatif. Dalam penelitian dengan judul Hubungan Fungsi Afektif Keluarga Dengan Kecerdasan Emosional Remaja di SMA Negeri 1 Kec. Panai Hulu Kab. Labuhan Batu pada tahun 2019 peneliti hanya melakukan penelitian dengan sekali waktu dan hanya mengambil variabel dependen dan variabel independennya. Karena sebab itu, peneliti menggunakan metode Cross Sectionak dalam melakukan penelitian ini. Sedangkan populasi yang dipilih dari penelitian ini adalah seluruh siswa yang ada di SMA Negeri $1 \mathrm{Kec}$. Panai Hulu Kab. Labuhan Batu tersebut dengan jumlah siswa 610 orang. Dan sampel yang diambil peneliti adalah 86 responden. Responden yang akan diambil menggunakan teknik Starified Random Sampling yang mana pemilihan responden dikelompokkan dengan pembagian kelas (Donsu. 2016).

Dalam melihat atau untuk mengetahui apakah ada Hubungan Fungsi Afektif Keluarga Dengan Kecerdasan Emosional Remaja di SMA Negeri $1 \mathrm{Kec}$. Panai Hulu Kab. Labuhan Batu pada tahun 2019, peneliti menggunakan uji Chi-Square (Donsu. 2016). Data - data diambil dari responden yaitu siswa yang ada di SMA Negeri $1 \mathrm{Kec}$.Panai Hulu Kab.Labuhan Batu dengan menggunakan kuesioner yang telah dibagikan kepada responden tersebut. 


\begin{tabular}{c|c|c|}
\hline $\begin{array}{c}\text { JURNALPENELITIAN KEPERAWATAN } \\
\text { MEDIK }\end{array}$ & VOL. 1 NO. 2 & $\begin{array}{c}\text { EDITION: NOVEMBER 2018- } \\
\text { APRIL 2019 }\end{array}$ \\
\hline & http://ejournal.delihusada.ac.id/index.php/JPKM & \\
\cline { 2 - 2 } RECEIVED: 20 JANUARI 2019 & REVISED: 24 MARET 2019 & ACCEPTED: 28 APRIL 2019 \\
\hline
\end{tabular}

\section{HASIL DAN PEMBAHASAN}

Berdasarkan hasil penelitian yang telah dilakukan terhadap 86 responden, didapatkan hasil sebagai berikut :

Tabel 1. Karakteristik responden

\begin{tabular}{clcc}
\hline No & Data Demografi & $\mathbf{F}$ & $\mathbf{\%}$ \\
\hline $\mathbf{1}$ & Jenis Kelamin : & & \\
& Laki-laki & 33 & $38,4 \%$ \\
& Perempuan & 53 & $61,6 \%$ \\
& Total & 86 & $100 \%$ \\
$\mathbf{2}$ & Usia : & & \\
& 15 Tahun & 29 & $33,7 \%$ \\
& 16 Tahun & 28 & $32,6 \%$ \\
& 17 Tahun & 29 & $33,7 \%$ \\
& Total & 86 & $100 \%$ \\
$\mathbf{3}$ & Kelas : & & \\
& X & 29 & $33,7 \%$ \\
& XI & 28 & $32,6 \%$ \\
& XII & 29 & $33,7 \%$ \\
& Total & 86 & $100 \%$ \\
\hline
\end{tabular}

Berdasarkan tabel1 dapat diketahui bahwa responden tertinggi pada penelitian ini yaitu pada kategori perempuan sebanyak 53 orang $(61,6 \%)$, responden tertinggi pada penelitian ini yaitu pada kategori umur 15 tahun dan 17 tahun sebanyak 29 orang $(33,7 \%)$, dan responden tertinggi pada penelitian ini yaitu pada kategori kelas $X$ dan kelas XII sebanyak 29 orang $(33,7 \%)$.

Tabel 2. Fungsi Afektif Keluarga

\begin{tabular}{cccc}
\hline No & Kategori & F & \% \\
\hline $\mathbf{1}$ & Baik & 71 & $82,6 \%$ \\
$\mathbf{2}$ & Kurang Baik & 15 & $17,4 \%$ \\
& Total & 86 & $100 \%$ \\
\hline
\end{tabular}

Berdasarkan tabel 2 dapat dilihat kalau responden tertinggi pada penelitian ini yaitu pada kategori baik sebanyak 71 orang $(82,6 \%)$, dan responden terendah pada penelitian ini yaitu pada kategori kurang baik sebanyak 15 orang $(17,4 \%)$.
Tabel 3. Kecerdasan Emosional Remaja

\begin{tabular}{cccc}
\hline No & Kategori & F & \% \\
\hline $\mathbf{1}$ & Cerdas & 73 & $84,9 \%$ \\
$\mathbf{2}$ & Kurang Cerdas & 13 & $15,1 \%$ \\
& Total & 86 & $100 \%$ \\
\hline
\end{tabular}

Berdasarkan tabel dapat dilihat kalau responden tertinggi pada penelitian ini yaitu pada kategori cerdas sebanyak 73 orang $(84,9 \%)$, dan responden terendah pada penelitian ini yaitu pada kategori kurang cerdas sebanyak 13 orang $(15,1 \%)$.

Tabel 4. Hubungan Fungsi Afektif Keluarga

Dengan Kecerdasan Emosional Remaja.

\begin{tabular}{lcccccc}
\hline \multirow{2}{*}{$\begin{array}{c}\text { Fungsi } \\
\text { Afektif }\end{array}$} & \multicolumn{4}{c}{$\begin{array}{c}\text { Kecerdasan } \\
\text { Emosional }\end{array}$} & \multirow{2}{*}{$\begin{array}{c}\text { p- } \\
\text { Keluarga }\end{array}$} & \multicolumn{2}{c}{ Cerdas } & \multicolumn{2}{c}{ Kurang } & & \\
& Value \\
& $\mathrm{F}$ & $\%$ & $\mathrm{~F}$ & $\%$ & $\mathrm{~F}$ & \\
\hline Baik & 64 & 90,2 & 7 & 9.8 & 71 & \\
Kurang & 9 & 60 & 6 & 40 & 15 & 0,003 \\
\hline Total & 73 & & 15 & & 86 & \\
\hline
\end{tabular}

Berdasarkan tabel 4, dapat dilihat bahwa dari 71 responden dengan fungsi afektif baik dengan kecerdasan emosional cerdas sebanyak 64 orang $(90,2 \%)$. Sedangkan dari 15 orang dengan fungsi afektif kurang baik dan kecerdasan emosional kurang. cerdas sebanyak 6 orang (40\%).

Hasil penelitian yang sudah dilakukan peneliti menunjukkan ada hubungan antara fungsi afektif keluarga dengan kecerdasan emosional remaja di SMA Negeri 1 Kecamatan Panai Hulu Kabupaten Labuhan Batu dengan nilai $p$-Value $=0,003<a=$ 0,05 yang dilihat peneliti dari hasil statistik yang sudah dilakukan dengan menggunakan uji Chi-Square.

Hasil penelitian yang telah dilakukan peneliti bahwa penelitian ini sejalan dengan penelitian yang telah dilakukan oleh Novi Afrianti dan Fithria (2017) dengan judul "Fungsi Afektif Keluarga Dengan Kecerdasan Emosional Remaja di SMP Negeri 5 Banda Aceh yang dilakukan pada 76 responden 


\begin{tabular}{|c|c|c|}
\hline $\begin{array}{l}\text { JURNALPENELITIAN KEPERAWATAN } \\
\text { MEDIK }\end{array}$ & VOL. 1 NO. 2 & $\begin{array}{l}\text { EDITION: NOVEMBER } 2018- \\
\text { APRIL } 2019\end{array}$ \\
\hline & http://ejournal.delihusada.ac.id/index.php/JPKM & \\
\hline RECEIVED: 20 JANUARI 2019 & REVISED: 24 MARET 2019 & ACCEPTED: 28 APRIL 2019 \\
\hline
\end{tabular}

menunjukkan bahwa adanya hubungan antara fungsi afektif keluarga dengan kecerdasan emosional remaja" (Afrianti, 2017). Dari penelitian yang telah dilakukan oleh Novi Afrianti dan Fithria (2017), penelitian tersebut ada hubungan antara fungsi afektif keluarga dengan kecerdasan emosional remaja. Peneliti berpendapat, "Apabila fungsi afektif dalam suatu keluarga baik atau bisa dikatakan keluarga tersebut harmonis maka kecerdasan emosional yang dimiliki anak tersebut akan semakin cerdas. Dan itu dapat disimpulkan bahwa sangat pentingnya fungsi afektif keluarga dalam suatu keluarga untuk meningkatkan kecerdasan emosional remaja tersebut" (Afrianti,2017).

Hasil penelitian yang telah dilakukan peneliti bahwa penelitian ini sejalan dengan penelitian yang telah dilakukan oleh Arie Kusumaningrum, Hesty Trilonggani, Nurhalinah (2016) dengan judul "Hubungan Fungsi Afektif Keluarga Dengan Kecerdasan Emosional Remaja di Kelurahan Timbangan Ogan Ilir yang dilakukan pada 84 responden menunjukkan bahwa adanya hubungan antara fungsi afektif keluarga dengan kecerdasan emosional remaja" (Kusumaningrum, 2016). Dari penelitian yang telah dilakukan Arie Kusumaningrum, Hesty Trilonggani, Nurhalinah (2016) penelitian tersebut ada hubungan antara fungsi afektif keluarga dengan kecerdasan emosional remaja. Peneliti menyimpulkan bahwa, "sangatlah penting peran sebuah keluarga dalam meningkatkan kecerdasan emosional yang dimiliki oleh sorang remaja" (Kusumaningrum, 2016).

Hasil penelitian yang telah dilakukan peneliti bahwa penelitian ini sejalan dengan penelitian yang telah dilakukan oleh Dwi Yuniar dan Irma Darmawati (2016) dengan judul "Dukungan Keluarga Berhubungan Dengan Kecerdasan Emosional Remaja di SMA Kota Bandung yang dilakukan pada 170 responden menunjukkan bahwa adanya hubungan yang signifikan antara fungsi afektif keluarga dengan kecerdasan emosional remaja" (Yuniar, 2016). Dari penelitian yang telah dilakukan Dwi Yuniar dan Irma Darmawati (2016) ) penelitian tersebut terdapat ada hubungan antara fungsi afektif keluarga dengan kecerdasan emosional remaja. Peneliti menyimpulkan bahwa, "Kecerdasan yang dimiliki remaja sangat bergantung dengan bagaimana fungsi afektif di dalam keluarganya" (Yuniar, 2016).

\section{KESIMPULAN}

Berdasarkan penelitian yang dilakukan peneliti bahwa dapat disipulkan bahwa adanya hubungan antara fungsi afektif dengan kecerdasan emosional remaja di SMA Negeri 1 Kecamatan Panai Hulu Kabupaten Labuhan Batu dengan $\mathrm{p}$-Value $=0,003<\mathrm{a}=$ 0,05 . Maka dari hasil penelitian yang didapat, peneliti beranggapan bahwa apabila remaja memperoleh fungsi afektif keluarga yang baik dari keluarganya kemungkinan besar kecerdasan emosional yang dimiliki remaja tersebut akan lebih baik.

Saran

1. Bagi Remaja

Remaja lebih paham dan lebih mengenali dirinya sendiri untuk melakukan aktifitas yang tidak merugikan dirinya sendiri.

2. Bagi Keluarga

Dalam hal ini keluarga sangat berperan penting, karena keluarga adalah kuci utama dari kecerdasan emoisonal yang dimiliki oleh remaja tersebut. Sebaiknya keluarga lebih berperan sebagai sahabat bagi remaja bukan malah remaja tersebut menganggap bahwa keluarga adalah musuhnya sendiri yang selalu mengatur aktifitas mereka. Remaja memiliki kebebasan, namun tugas keluarga hanyalah memantau dan memberi contoh yang terbaik untuk remaja tersebut.

3. Bagi Sekolah

Dalam hal ini pihak sekolah khusunya yang menangani bidang kesiswaan bekerja sama dengan orangtua remaja untuk saling 


\begin{tabular}{|c|c|c|}
\hline $\begin{array}{l}\text { JURNALPENELITIAN KEPERAWATAN } \\
\text { MEDIK }\end{array}$ & VOL. 1 NO. 2 & $\begin{array}{l}\text { EDITION: NOVEMBER } 2018- \\
\text { APRIL } 2019\end{array}$ \\
\hline & http://ejournal.delihusada.ac.id/index.php/JPKM & \\
\hline RECEIVED: 20 JANUARI 2019 & REVISED: 24 MARET 2019 & ACCEPTED: 28 APRIL 2019 \\
\hline
\end{tabular}

berkomunikasi dan saling bekerjasama dalam setiap perkembangan yang dilakukan remaja tersebut.

4. Bagi Perawat

Pada masalah ini perawat hanya berfungsi sebagai konselor yaitu menentukan perencanaan dalam bidang nya yaitu keperawatan untuk mengkaji mental dan psikis remaja tersebiut untuk mengetahuo peerkembangan emosional yang terjadi pada remaja tersebut.

\section{DAFTAR PUSTAKA}

Afrianti, N \& Fithria. (2017). Fungsi Afektif Keluarga Terhadap Kecerdasan Emosional Remaja. Jurnal Keperawatan Komprehensif.

Donsu (2016). Metodologi Penelitian Keperawatan. Yogyakarta: PT. Pustaka Baru.

Goelman, D. (2018). Emotional Intelligence. Jakarta: PT Gramedia.
Gusti, S. (2017). Asuhan Keperawatan Keluarga. Jakarta: Trans Info Media.

Kusumaningrum, A \& Triolonggani H. (2016). Hubungan Fungsi Afektif Keluarga Terhadap Kecerdasan Emosional Remaja. Jurnal Keperawatan Vol. 2.

Nadhirin. (2009). Instrumen Penelitian Kecerdasan Emosional. Yogyakarta: http://nadhirin.blogspot.com/.

Rohmad (2009). Hubungan Fungsi Keluarga Terhadap Kecerdasan Emosional Remaja. Jurnal Soul Vol. 1 No. 1.

Sobur, A. (2016). Psikologi Umum. Bandung: CV Pustika Setia.

Sugiyono (2017). Metode Penelitian Kuantitatif, Kualitatif, dan R\&D. Bandung: Alfabeta.

Yuniar, D \& Irma D. (2016). Dukungan Keluarga Berhubungan Dengan Kecerdasan Emosional Remaja. Jurnal Keperawatan Komprehensif Vol. 3 No. 1 Januari 2017, 9-17. 